\title{
Scientific Substantiation of Introduction of Differentiated Agricultural Systems, Increase of Productivity of Agricultural Production
}

\author{
AI Ismailov and Aliyev ZH* \\ Institute of Soil Science and Agrochemistry of NAS, Azerbaijan
}

Submission: April 18, 2018; Published: May 14, 2018

*Corresponding author: Aliyev ZH, Institute of Soil Science and Agrochemistry of NAS, Azerbaijan, Email: volqa_5@mail.ru

Abstract

As a result of the agrarian reforms implemented in the Republic of Azerbaijan, the basis for the dynamic development of agriculture was created. Major changes have been made in the agrarian sector, new economic and property relations have been formed, the normative legal base has been improved. An important issue has been raised to improve the quality of erosion lands and the productivity of agricultural crops.

Keywords: Humus; Soil; Erosion; Layer; Ostepennye; Not washed

\section{Introduction}

For solving various practical issues and in the first place, the most rational distribution of crops and increase their productivity soil must be evaluated, taking into account their quality and its changing under the influence of industrial activity.

To that end, it had explored common at the site soil research natural areas. Their evaluation was performed from the basis of agrochemical and water-physical properties of soils, impact their erosion and yield of different Soils crop farming zone estimated reserves of humus, nitrogen, phosphorus, absorption capacity and some water-physical properties in $0-20 \mathrm{~cm} 0-50 \mathrm{~cm}$ and $0-100 \mathrm{~cm}$ of soil layers.

Scientific and reasonable accommodation, differentiated farming system on the basis of the evaluation provides an opportunity to improve crop productivity. Among soils agricultural zone natural fertility indicators highest impact mining nesmytye Brown ostepnennye soil. Taken as a "benchmark". Points remaining soils distributed in these areas also are calculated as a percentage of the standard. To manage associations and groupings of soils comprising the agricultural zone and heavily used in agricultural production, they are grouped into the following five groups: land better, good, medium, low and very low dignity. In a fairly fractional grouping soil laid down the objective indicators of soil fertility and their productivity [1].

At the same time grouping based on commonality land allows rationally and purposefully uses soil from the agricultural point of view. The following will focus on agroproizvodstvennoj characteristic of designated groups. $S$ Group-land better dignity. This group includes mining and nesmytye Brown ostepnennye soil, area of 9565, 0 hectares or $23,89 \%$ of the total area of agricultural areas of evaluation scores 81 .

Stocks of humus, gross phosphorus and nitrogen absorption capacity in $0-20 \mathrm{~cm}$ of soil layers is $124,11 \mathrm{t} / \mathrm{ha}$; $7,23 \mathrm{t} / \mathrm{ha} ; 6,21 \mathrm{t} / \mathrm{ha}$ and $38,87 \mathrm{mg} / \mathrm{eq}$ on $100 \mathrm{~g}$ of soil in $0-50 \mathrm{~cm}$ layers respectively $223,42 \mathrm{t} / \mathrm{ha} ; 15,41 \mathrm{t} / \mathrm{ha} ; 12,62$ tons/ha and $38,17 \mathrm{mg} / \mathrm{eq}$ on $100 \mathrm{~g}$ of soil, and in $0-100 \mathrm{~cm}$ layers of $327,32 \mathrm{t} /$ ha; $18.26 \mathrm{t} / \mathrm{ha}$; $17,65 \mathrm{t} / \mathrm{ha}$ and $\mathrm{mg} / \mathrm{eq} 41,23$ on $100 \mathrm{~g}$ of soil [2].

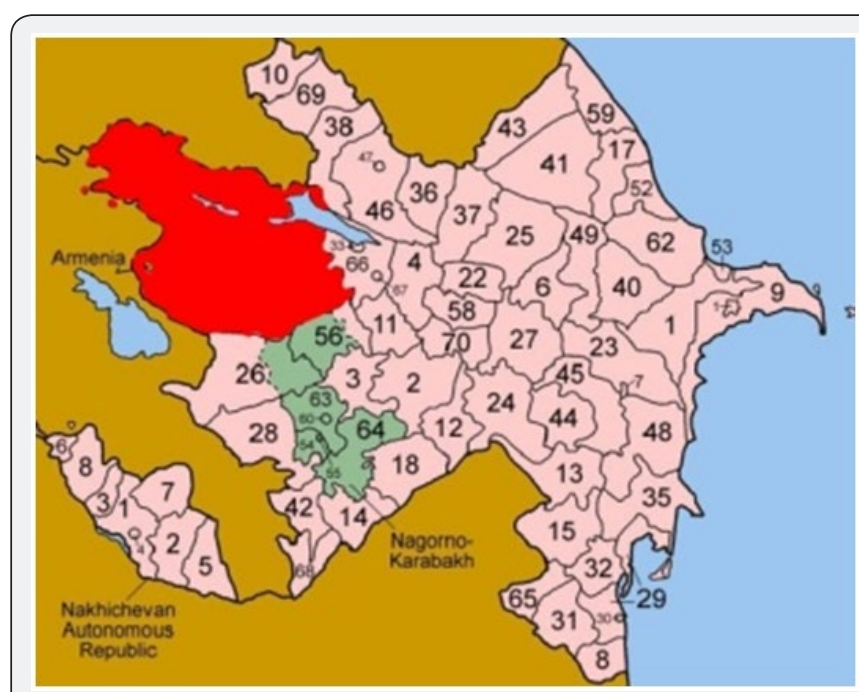

Figure 1: 
For soils of this group did not require special erosion control activities. In order to maintain the natural fertility of these soils vineyards, ploughing, seeding and tillage should be conducted across a slope, to observe the erosion, and agricultural activities. ENJOY Group-land of good merit the land Area is 13783.5 hectares, or $11.24 \%$ of the total area of agricultural zone. They are priced ranging from 61 to 80 points on the bonitetnoj scale. This group includes the slabosmytye mountain-Brown, ostepnennye nesmytye and slabosmytye mountain grey-brown, nesmytye and slabosmytye mountain dark brown (dark grey-brown) and floodplain meadow soils Figure 1.

Stocks see 0-20 layer of humus in these soils reach 57, 63 -95, $12 \mathrm{t} / \mathrm{ha}, 0-50 \mathrm{~cm}$ layers of $131,89-208,20 \mathrm{t} / \mathrm{ha}$, and the meter layers 186, $44-301,32 t /$ ha. Compared with the first group, this group is less assured in nutrients. Gross nitrogen content and gross phosphorus in $0-20 \mathrm{~cm}$ kalebletsja layer in the range from 3.57 to 5.29 tons/ha and $3.28-4.97 \mathrm{t} / \mathrm{ha}, 0-50 \mathrm{~cm}$ layers of 7,80 $-11,31 \mathrm{t} / \mathrm{ha}$ and $7,80-11,60 \mathrm{t} / \mathrm{ha}$, and the meter layers respectively $9.10-16.12 t /$ ha and $11.16-18.88 \mathrm{t} / \mathrm{ha}$. In $0-20$, see tank takeover layers varies between-36.27 $28.32 \mathrm{mg} / \mathrm{eq}$ on $100 \mathrm{~g}$ of soil, and in $0-50 \mathrm{~cm}$ layers respectively $27.50-36.04 \mathrm{mg} /$ eq on $100 \mathrm{~g}$ of soil. When you use these lands must follow the General Agro technical measures protective nature envisaged for lands S Group [3]. To maintain and improve the productivity of vegetation and prevent erosion on pasture standards must be respected to settlements pastures for and enter the moving system of grazing, to make chemical fertilizers. Good graphics, decent game play Group-land of the middle area of the dignity in that group of soils is 8130,0 hectares or $20,30 \%$ of the total area of the agricultural area.

These soils are evaluated in 41-60 points. This group comprises small and srednesmytye mining-Brown, ostepnennye slabosmytye mountain grey-brown, slabosmytye mountain-dark brown (dark grey-brown) and the nesmytye mountain light brown (light greyish-Brown) soil. In these soils, stockpiles of humus, gross gross phosphorus and nitrogen absorption capacity in $0-20 \mathrm{~cm}$ layer vary between $60.24-63.01 \mathrm{t} / \mathrm{ha}, 3.78-3.84 \mathrm{t} / \mathrm{ha},-3,352,83 \mathrm{t} / \mathrm{ha}$ and 28,77 $-30,43 \mathrm{mg} / \mathrm{eq}$ on $100 \mathrm{~g}$ of soil, and in $0-50 \mathrm{~cm}$ layer $87,78-131,89$ respectively, t/ha, 5,32m/ $-7.86 \mathrm{ha},-6,055,99 \mathrm{t} / \mathrm{ha}$ and 27,71 $-30,17 \mathrm{mg} /$ eq on $100 \mathrm{~g}$ of soil [4].

When using the medium need dignity lands activities implement agro technical measures of a general nature applicable to land first and second teams, and the eroded sections carry out anti-erosion agricultural activities. The eroded areas of arable land use strip crops and strip buffers from perennial grasses. If necessary, a small part of the plots on arboraceous over $20^{\circ}$ used for crops, perennial grasses, then using them as hayfields. Introduced mineral fertilizers.
On slobosmytyh sites, reduce grazing on rule $25 \%$ due to nejerodirovannyh plots and observe the sequence of grazing. Rocky areas cleared of stones. YV Group-land of low land worthiness this group is 8115,0 hectares or $20,27 \%$ of the total area of agricultural zones, they are priced from 21 to 40 points. This group includes the silnosmytye mountain-Brown ostepnennye, medium and silnosmytye mountain-Brown, medium and silnosmytye mountain dark brown (dark greybrown) and the slobosmytye mountain light brown (light greyish-Brown) soil [5].

Stocks of humus in $0-20$ see these layers of soil reach 36.83 $-60.72 \mathrm{t} / \mathrm{ha}$, polumetrovyh layers of $73,36-115,29 \mathrm{t} / \mathrm{ha}$, and the meter layers 126,69 -241,80 t/ha. Gross reserves of nitrogen vary in $0-20$ see layers from 2.79 to $3.84 \mathrm{t} / \mathrm{ha}$, gross phosphorus $1,78-3,00 \mathrm{t} / \mathrm{ha}$, absorption capacity $-29,6526,16 \mathrm{mg} / \mathrm{eq}$ on $100 \mathrm{~g}$ of soil, and in $0-50 \mathrm{~cm}$ layers accordingly: from 5,32 to $5,90 \mathrm{t} /$ ha, 3,93 $-6,30 \mathrm{t} / \mathrm{ha}$, and 23,84 $-27,86 \mathrm{mg} / \mathrm{eq}$ on $100 \mathrm{~g}$ of soil [6].

To restore the soil fertility in srednesmytyh and silnosmytyh areas it is necessary to carry out the planting of perennial grasses and apply erosion event, featured for all previous groups to settlements pastures for pasture grazing rules on reduced $50 \%$.

In Group-very low land worthiness. This group includes silnosmytye mountain gray-Brown and Silnosmytye Mountain dark brown (dark grey-brown) soils and evaluated up to 20 credits. These lands is 667.5 hectares or $1.67 \%$ of the total area agricultural zone. Stocks of humus, gross phosphorus and nitrogen absorption capacity in $0-20 \mathrm{~cm}$ layer accounted for 33.26-36.54 t/ha; $2.02-2.42 \mathrm{t} / \mathrm{ha}$; $1.51-1.94 \mathrm{t} / \mathrm{ha}$ and 25.02 $-26.40 \mathrm{mg} / \mathrm{eq}$, and in $0-50 \mathrm{~cm}$ layer respectively $78.08-81.25 \mathrm{t} /$ ha; $-5.003 .84 \mathrm{t} / \mathrm{ha} ; 3.20-3.75 \mathrm{t} / \mathrm{ha}$ and $-24.8223 .56 \mathrm{mg} / \mathrm{eq}$ on $100 \mathrm{~g}$ of soil. When you use these lands must observe activities previous land groups, and to restore the strongly rarefied grass would need additional erosion event, stone-clearing, etc.

\section{References}

1. Aliyev HA (1978) Soils of the big Caucasus within the Azerbaijan SSR, Baku, Azerbaijan, "Elm”, p. 157.

2. Aliyev BH, Aliyev ZH Aliyev (2000) Erosion Problems in Azerbaijan and ways of its solution. IZD-vo Zia-CPI «Nurlan” p. 128.

3. Aliev BH, Aliyev ZH (2007) Background on the crucial issue of agriculture in ensuring water resources management mountain and Foothill areas of Azerbaijan. J. AAE. № 1-3, Baku, Azerbaijan, pp. 179182.

4. Babayev MP, Jafarov AM (2017) Etc-modern soil cover of the Greater Caucasus, Baku, Azerbaijan p. 344.

5. Mamedov G (1979) Sh. land cadastre."Ed. An Azeri. SSR SER. biol. Sciences.

6. Sobolev S (1972) S-on bantirovke soils. proc. Moscow forestry engineering, Russia Ying-TA". 
This work is licensed under Creative Commons Attribution 4.0 License

\section{Your next submission with Juniper Publishers will reach you the below assets}

- Quality Editorial service

- Swift Peer Review

- Reprints availability

- E-prints Service

- Manuscript Podcast for convenient understanding

- Global attainment for your research

- Manuscript accessibility in different formats ( Pdf, E-pub, Full Text, Audio)

- Unceasing customer service

Track the below URL for one-step submission https://juniperpublishers.com/online-submission.php 